\title{
The Relationship of Community-Based Total Sanitation with Stunting Incidences in Toddlers
}

\author{
Auliya Fajriyati, Novita Rany, Jasrida Yunita, Oktavia Dewi, Emy Leonita
}

School of Health Sciences Hang Tuah, Pekanbaru, Indonesia

\section{ABSTRACT}

Background: Stunting is a condition where toddlers have a length or height that is less than their age. The prevalence of stunting in Riau Province in 2019 based on survey data on the nutritional status of Indonesian toddlers was $23.7 \%$, at the Sidomulyo Health Center there were 161 stunting toddlers and the results of the study found stunting toddlers $36.9 \%$. The purpose of this study was to determine the relationship between Community Based Total Sanitation (CBTS) and the incidence of stunting in children under five in the working area of the Sidomulyo Health Center Pekanbaru City in 2021.

Subjects and Method: The cross-sectional study was conducted in the working area of the Sidomulyo Public Health Center, Pekanbaru, Riau, Sumatra from July to August 2021. A total of 163 subjects were selected in this study using a purposive sampling technique. The dependent variable is the incidence of stunting. The independent variables are open defecation (stop defecation), hand washing with soap, household drinking water and food management, household waste protection, and household liquid waste protection. Data were collected using a questionnaire and analyzed using chi-square test and multiple regression test.

Results: Open defecation $(\mathrm{OR}=20.25 ; 95 \% \mathrm{CI}=6.59$ to $62.15 ; \mathrm{p}<0.001)$, household waste management $(\mathrm{OR}=13.84 ; 95 \% \mathrm{CI}=6.27$ to $30.55 ; \mathrm{p}<0.001)$, household waste $(\mathrm{OR}=11.91 ; 95 \% \mathrm{CI}=$ 5.53 to $25.58 ; \mathrm{p}<0.001)$ associated with stunting and was statistically significant.

Conclusion: Open defecation, household waste, household waste are associated with stunting and are statistically significant.

Keywords: toddler, Community Based Total Sanitation, stunting

\section{Correspondence:}

Auliya Fajriyati. School of Health Sciences Hang Tuah, Pekanbaru, Indonesia. Jl. Mustafa Sari No.5, Tengkerang Selatan, Bukit Raya, Pekanbaru, Riau. Email: auliyafrh@gmail.com. Mobile: +6281261668168 .

\section{Cite this as:}

Fajriyati A, Rany N, Yunita J, Dewi O, Leonita E (2021). The Relationship of Community-Based Total Sanitation with Stunting Incidences in Toddlers. J Health Promot Behav. 06(03): 224-232. https://doi.org/10.26911/thejhpb.2021.06.03.06.

(c) (1) (2) Journal of Health Promotion and Behavioris licensed under a Creative Commons Attribution-NonCommercial-ShareAlike 4.o International License.

\section{BACKGROUND}

Under-five stunting is a chronic nutritional problem caused by many factors such as socioeconomic conditions, maternal nutrition during pregnancy, infant morbidity, and lack of nutritional intake for infants. Stunting toddlers in the future will have difficulty in achieving optimal physical and cognitive development (Riskesdas, 2018).
Data on the prevalence of stunting under five were collected by the World Health Organization (WHO), Indonesia is included in the third country with the highest prevalence in the Southeast Asia/South-East Asia Regional (SEAR) region. The average prevalence of stunting under five in Indonesia in 2005-2017 was $36.4 \%$. The incidence of stunting (short) toddlers is a major nutri- 
tional problem faced by Indonesia. Based on nutritional status monitoring data for the last three years, shortness has the highest prevalence compared to other nutritional problems such as undernutrition, thinness, and obesity.

Referring to the UNICEF mindset, the problem of stunting is mainly due to the influence of parenting, coverage and quality of health services, the environment, as well as food security, at the family level. Indirect factors that affect stunting include sanitation factors that influence the incidence of stunting. Therefore, as an effort from the government in tackling these indirect factors, the Community-Based Total Sanitation (CBTS) program can be implemented by making gradual behavioral changes to achieve better and sustainable conditions of sanitation hygiene and stunting prevention.

The purpose of implementing the CBTS Program is to realize hygienic, sanitary behavior in the community and implement a lifestyle with good nutrition. The CBTS program includes the five CBTS pillars in order to improve the health status of the community as high as possible, the five CBTS pillars, including: stop open defecation, washing hands with soap, management of drinking water and food in the household, household waste protection, household liquid waste protection, besides that there are 3 additional pillars through the CBTS-stunting approach, namely nutrition for pregnant women, provision of supplementary feeding for infants and children and growth monitoring (Ministry of Health, 2017 ).

According to Herawati's research in 2020 about the relationship between sanitation facilities, occupant behavior and the habit of washing hands with soap by mothers with stunting in toddlers aged 624 months in the work area of the Harapan Baru Health Center, Samarinda which sta- ted $68.4 \%$ of respondents who do not have the quality of washing hands using soap habit that meet the requirements.

Based on data from the Sidomulyo Health Center, there are 3 villages in the working area of the Sidomulyo Health Center, namely Tuah Karya, Tuah Madani, and Sialang Munggu Villages. Based on the results of interviews in the initial survey to 2 mothers who have toddlers who are in the work area of the Sidomulyo Health Center in preventing stunting, in addition to paying attention to the nutritional intake of toddlers, one of which is to keep the living environment clean. However, one in 2 mothers stated that they still have limitations in providing nutritious food due to economic factors, so they cannot meet the nutritional needs of toddlers.

\section{SUBJECTS AND METHOD}

\section{Study Design}

This was a cross-sectional study conducted at Sidomulyo Health Center, Pekanbaru, Riau, Indonesia, from July to August 2021.

\section{Population and Sample}

The population in this study were children under five who were in the working area of the Sidomulyo Health Center, Pekanbaru, Riau. The number of subjects selected was 163 and selected by purposive sampling.

\section{Study Variables}

The independent variables are stop open defecation, hand washing with soap, household drinking water and food management, household waste protection and household liquid waste management. The dependent variable is Stunting Incidence.

4. Operational Definition of Variables The incidence of stunting is a toddler's height according to age (HAZ) less than -2 standard deviations (SD) so that it is shorter than the height that should be measured in toddlers. 
Fajriyati et al./ Community-Based Total Sanitation with Stunting Incidences in Toddlers

Stop open defecation is a situation when people throw their feces into the toilet, everyone in the house uses the toilet, no human feces can be seen around the house, garden, river.

Hand washing with soap is the availability of running water in the house, soap is available for washing hands, there is hand washing equipment in the house, and at least every family member knows when it is important to wash hands.

Household drinking water and food management is the management of drinking water and household food is declared good if it always manages water before drinking, drinking water that has been treated is stored in tightly closed containers, food is served in closed containers and drinking cleaned regularly (at least once a week).

Household waste protection is a condition when solid waste is not scattered in the yard.

\section{Safeguarding household liquid waste} is a condition if there is no standing water around the house due to domestic waste, liquid waste has been treated before being disposed of.

\section{Study instruments}

The data used in this study are primary data and secondary data. Primary data was obtained using a questionnaire. Secondary data was obtained from the Sidomulyo Health Center, Pekanbaru, Riau, namely data on toddlers who were in the working area of the Sidomulyo Health Center.

\section{Data Analysis}

Univariate analysis was used to see the frequency distribution of research variables. Bivariate analysis using the chi-square test was used to determine the significance of the relationship between each independent and dependent variable, while multivariate analysis using multiple regression tests was used to analyze the relation- ship between one or several independent variables with a dichotomous/binary categorical dependent variable.

\section{RESULTS}

\section{Univariate Analysis}

Table 1 shows that as many as 60 toddlers are stunted (36.9\%), and those who are not stunted are 103 toddlers (63.2\%).

Table 2 shows that the majority of toddlers live in an environment that does not open defecation as many as 132 people (81\%), toddlers whose mothers do not wash their hands with soap are 89 people (54.6\%), 90 people $(55.2 \%)$ have mothers with bad behavior in household drinking water and food management, 110 people $(67,2 \%)$ have mothers with good behavior in household waste protection. $5 \%$ ) and the majority of children under five who have mothers with good behavior in household liquid waste protection are 92 people (56.4\%).

\section{Bivariate Analysis}

Table 3 shows the chi-square results of the relationship between open defecation, hand washing with soap, household food drinking water management, household waste management, household waste management on the incidence of stunting. Open defecation $(\mathrm{OR}=20.25 ; 95 \% \mathrm{CI}=6.59$ to 62.15; $\mathrm{p}<0.001$ ), household waste management $(\mathrm{OR}=13.84 ; 95 \% \mathrm{CI}=6.27$ to 30.55 ; $\mathrm{p}<0.001)$, household waste $(\mathrm{OR}=11.91$; $95 \% \mathrm{CI}=5.53$ to 25.58 ; $\mathrm{p}<0.001)$ associated with stunting and was statistically significant.

\section{Multivariate Analysis}

Table 4 shows that the most dominant factors for stunting are open defecation (OR= 28.13; $95 \% \mathrm{CI}=6.68$ to $118.41 ; \mathrm{p}<0.001)$, safeguarding household liquid waste $(\mathrm{OR}=$ 10.08; 95\% $\mathrm{CI}=3.59$ to 28.27 ; $<<0.001)$, and household waste protection $(\mathrm{OR}=6.35$; $95 \% \mathrm{CI}=2.37$ to $16.99 ; \mathrm{p}<0.001$ ). 
Fajriyati et al./ Community-Based Total Sanitation with Stunting Incidences in Toddlers

Table 1. Frequency Distribution the Case of stunting

\begin{tabular}{cccc}
\hline Variable & Category & Frequency (n) & Percentage (\%) \\
\hline Stunting Cases & Stunting & 60 & 36,9 \\
& Not Stunting & 103 & 63,1 \\
\hline
\end{tabular}

Table 2. Frequency distribution (dichotomous data) of independent variables

\begin{tabular}{lccc}
\hline \multicolumn{1}{c}{ Variable } & Category & $\begin{array}{c}\text { Frequency } \\
\text { (n) }\end{array}$ & $\begin{array}{c}\text { Percentage } \\
\text { (\%) }\end{array}$ \\
\hline Defecation indiscriminately & Yes & 31 & 19 \\
Washing hands with soap & No & 132 & 81 \\
& Yes & 74 & 45.4 \\
Household food drinking water management & No & 89 & 54.6 \\
& Yes & 73 & 44.8 \\
Household Waste Management & No & 90 & 55.2 \\
& Yes & 110 & 67.5 \\
Household Liquid Waste Management & No & 53 & 32.5 \\
& Yes & 92 & 56.4 \\
& No & 71 & 43.6 \\
\hline
\end{tabular}

Table 3. Relationship of Community-Based Total Sanitation with Stunting Incidence in Toddlers in Sidomulyo Health Center Pekanbaru in 2021

\begin{tabular}{|c|c|c|c|c|c|c|c|c|}
\hline \multirow{3}{*}{ Variable Group } & \multicolumn{4}{|c|}{ Stunting Case } & \multirow{3}{*}{ OR } & \multirow{2}{*}{\multicolumn{2}{|c|}{$95 \% \mathrm{CI}$}} & \multirow{3}{*}{$\mathbf{p}$} \\
\hline & \multicolumn{2}{|c|}{ Stunting } & \multicolumn{2}{|c|}{$\begin{array}{c}\text { No } \\
\text { stunting }\end{array}$} & & & & \\
\hline & $\mathbf{n}$ & $\%$ & $\mathbf{n}$ & $\%$ & & $\begin{array}{l}\text { Lower } \\
\text { Limit }\end{array}$ & $\begin{array}{l}\text { Upper } \\
\text { Limit }\end{array}$ & \\
\hline \multicolumn{9}{|c|}{ Defecation indiscriminately } \\
\hline $\begin{array}{l}\text { Defecation } \\
\text { indiscriminately }\end{array}$ & 27 & 87.1 & 4 & 12.9 & 20.25 & 6.59 & 62.15 & $<0.001$ \\
\hline $\begin{array}{l}\text { Do not defecate } \\
\text { carelessly }\end{array}$ & 33 & 25 & 99 & 75 & & & & \\
\hline \multicolumn{9}{|c|}{ Washing hands using soap } \\
\hline No & 53 & 59.6 & 36 & 40.4 & 14.09 & 5.80 & 34.18 & $<0.001$ \\
\hline Yes & 7 & 9.5 & 67 & 90.5 & & & & \\
\hline \multicolumn{9}{|c|}{$\begin{array}{l}\text { Household Food Drinking Water } \\
\text { Management }\end{array}$} \\
\hline Poor & 60 & 66.7 & 30 & 33.3 & - & & & $<0.001$ \\
\hline Good & o & o & 73 & 100 & & & & \\
\hline \multicolumn{9}{|c|}{ Household Waste Management } \\
\hline $\begin{array}{l}\text { No Household Waste } \\
\text { Management }\end{array}$ & 40 & 75,5 & 13 & 24,5 & 13.84 & 6.27 & 30.55 & $<0.001$ \\
\hline $\begin{array}{l}\text { Household Waste } \\
\text { Management }\end{array}$ & 20 & 18,2 & 90 & 81,8 & & & & \\
\hline \multicolumn{9}{|c|}{ Household Waste Management } \\
\hline $\begin{array}{l}\text { No Household Waste } \\
\text { Management }\end{array}$ & 47 & 66.2 & 24 & 33.8 & 11.91 & 5.53 & $25 \cdot 58$ & $<0.001$ \\
\hline $\begin{array}{l}\text { Household Waste } \\
\text { Management }\end{array}$ & 13 & 14.1 & 79 & $85 \cdot 9$ & & & & \\
\hline
\end{tabular}

Table 4. Results of multiple logistic regression analysis 
Fajriyati et al./ Community-Based Total Sanitation with Stunting Incidences in Toddlers

\begin{tabular}{lcccc}
\hline \multirow{1}{*}{ Variable } & \multirow{2}{c}{ OR } & Lower & Upper & p \\
\cline { 3 - 4 } & & limit & limit & \\
\hline Open Defecation & 28.13 & 6.68 & 118.41 & 0,000 \\
Household waste protection & 6.35 & 2.37 & 16.99 & 0,000 \\
Safeguarding Household Liquid Waste & 10.08 & 3.59 & 28.27 & 0,000 \\
N Observation = 163 & & & & \\
-2 log Likelihood = 114.670 & & & & \\
Negelkerke $\mathrm{R}^{2}=0.626$ & & & \\
\hline
\end{tabular}

\section{Defecation indiscriminately}

Clean and healthy living behavior by utilizing sanitary sanitation facilities such as healthy latrines, the condition of sanitation facilities that meet health requirements and according to standards is a sanitary condition with a positive impact on the body by not causing the direct spread of materials that are harmful to the human body. From the impact of waste disposal and preventing dangerous vectors that can spread to the surrounding environment, healthy latrines are very effective in breaking the chain of disease spread, and every household must provide representative and easily accessible sanitation facilities (Permenkes, 2014).

This research is in line with the study conducted by (Mukti, 2016) which found that $86.4 \%$ of respondents did not use unhealthy latrines such as latrines without septic tanks and toilets. Crocker (2017) found that more than $60 \%$ had no bowel movements on the floor in Euthopia and Ghana. Meanwhile, in this study, it was found that the majority of respondents had not defecated properly and did not experience stunting (Anggraini, 2020; Ahmadi, 2020).

The stunting rate in the area is still found in addition to the food intake factor in 1,000 days of life, this is due to the fact that there are still open defecation, even though they only dispose of diapers without removing feces first. And there are still some respondents who are still open defec- ation, because there are elderly who are sick and lying in bed and do not use diapers because of economic limitations to buy diapers so that the elderly require to defecate in bed and be accommodated using a bucket and toddlers who are said to be defecating openly are throwing out diapers without removing the feces or excrement first and throwing them directly into the trash or plastic bins.

According to the researcher's assumption, the quality of community sanitation in the working area of the Sidomulyo East Health Center in Pekanbaru City is one of them by not defecating indiscriminately so that it does not cause stunting in toddlers, which is the output of multi-aspects that cannot be separated from the urban community where the people in the working area are classified as people with a good economic level so that they can and are able to provide proper latrines for members of all family members, supported by a good level of education so that they know the benefits of sanitation for health, the absence of stunting due to open defecation is one of the challenges measuring the success of the CBTS program for the Sidomulyo Public Health Center due to changes in community behavior that cares about sanitation and environmental factors are the biggest factors in influencing community behavior. And the potential for the community to dispose of feces indiscriminately is also not available where the land in the working area of the Sidomulyo Health Center does 
not have a river that can be used as a human waste disposal stream that has the potential as a breeding ground for vectors such as flies that act as carriers of disease through feces (faecal borne disease). placing their eggs in exposed human feces, and perching on food that can cause diseases to humans such as stunting, diarrhea, cholera and some gastro-intestinal diseases or potential parasitic infections.

\section{Wash your hands with soap}

Conceptually UNICEF released a statement that using soap when washing stairs is one simple step to prevent the risk of pain for the body, if only with running water washing hands this is not very effective in warding off germs when compared to washing hands using soap. After defecating and before touching food, washing hands with soap can reduce the risk of gastro-intestinal disease or discomfort in the digestive tract.

The results of this study are in line with Mukti (2016), it was found that $76 \%$ of respondents experienced diarrhea due to not washing their hands with soap properly, and research conducted by (Budiman, 2011) found that $78 \%$ of respondents still lacked washing practices. hands with soap, (Ahmadi, 2020) it was found that (79.3\%) had washed their hands with soap and had low risk of stunting.

According to the researcher's assumptions, the habit of washing hands with soap before carrying out activities, especially providing food intake for babies carried out by the community in the working area of the Sidomulyo Public Health Center is very good. A representative faucet for mothers to wash their hands coupled with the corona pandemic, one of the health protocols, namely washing hands using soap and running water so as to increase public awareness to improve a clean and healthy lifestyle, from good behavior and knowledge it has a positive impact on their babies with no risk of stunting in toddlers, even though the number of people who do not wash their hands with small soap is only $7 \%$, and the risk of stunting is not found, this shows that the community is aware of the risks that are not good for themselves and their toddlers if they don't wash their hands with soap when doing activities such as providing food for their toddlers

\section{Household Drinking Water and Food Management}

Before using water, it must be managed first before it is used until the health requirements for drinking water and household needs are met, the purpose of drinking water management is to fulfill physical, biological and chemical requirements (Dainur, 2015) and food management, food ingredients management with good and right will be beneficial for the health of the body, good management is such as carrying out the principles of hygiene and food sanitation (Permenkes, 2014).

This study is in line with Syam (2020) it was found that $56.7 \%$ of respondents had implemented household drinking water and food management well and stunting did not occur, (Mukti, 2016), it was found that 66.7\% had not implemented household drinking water and food management safely or well so diarrhea was still occurs, (Crocker, 2017) the results obtained from treating drinking water at home $(\mathrm{p}<0.001)$ in Euthopia and Ghana and in this study it was found that respondents had implemented household drinking water and food management and stunting did not occur in toddlers. Stunting cases are still found, it could be due to inadequate drinking water treatment, or contaminated water and undercooked processed food.

The researcher's assumption is that the safe management of household food and beverages has been going well. One of the 3 CBTS pillars in the working area of the 
Sidomulyo Health Center has been running properly. The community has cultivated the behavior of washing food ingredients before they are processed or cooked, using clean water for daily drinking purposes, getting used to selective behavior when choosing food ingredients such as (non-formalin consumed meat, non-formalin noodles, and meatballs that do not contain borax), and cultivate the behavior of storing food in a closed place or using a serving hood.

This shows that the community in the working area of the Sidomulyo Public Health Center already has good knowledge about food and beverage sanitation. Adequate knowledge about food and beverage sanitation will greatly affect the hygiene of food processors, the safety of the processing, and the quality of the food produced. The positive impact of the selective behavior of the community is that there is no relationship between Drinking Water and Household Food Management.

\section{Household Waste Management}

Garbage is one of the breeding grounds for vectors of disease sources such as flies, rats, mosquitoes and cockroaches. Inappropriate forms of waste management such as the construction of trash bins that are not used in a sanitary manner such as not having a cover so that they can become a breeding ground for disease and also littering in gardens or streams.

A study by (Budiman, 2011) has not managed household waste properly and the occurrence of diarrhea is 64\%, (Margareth, 2011) it is found that $78.8 \%$ of respondents do not accept waste management properly and diarrhea occurs. While in this study, respondents had implemented household waste management well and did not experience stunting. The incidence of stunting is still found because of the scattered garbage, which brings flies and lands on the food eaten by toddlers.
According to the researcher's assumptions, the management of household waste that has been going well and no relationship was found with the incidence of stunting shows that various program sectors are running in the working area of the Sidomulyo Health Center, both inter-program and cross-program collaboration, such as the effectiveness of posyandu cadres in campaigning for clean and healthy living as well as collaboration.

Cross programs such as with community leaders in waste management, in general the community has utilized the waste disposal services facilitated by the city government, and the potential for littering is very small because the working area of the Sidomulyo Public Health Center is geographically different from rural areas where still use rivers and vacant land to dispose of and burn garbage.

\section{Household Liquid Waste Management}

The proliferation of diseases caused by sewage can occur as a result of pooling of household liquid waste, and the Indonesian Ministry of Health (2014) has standardized the principles of household liquid waste such as not mixing bathroom waste with five latrine water, avoiding the breeding ground for disease vectors, should not cause odors and odors. there should be no puddles and public sewers or sewers or infiltration wells connected.

Margareth (2011) showed that 80.3\% of respondents experienced polluted environmental conditions, because not managing household waste fluids properly caused diarrhea, (Budiman, 2011) it was found that respondents had disposed of household waste fluids in shelters even though s still occurs and in this study it was found that the management of household waste fluids had been carried out properly so that stunting did not occur and if there 
were still stunting incidents, it was due to food contamination that was infested by flies that previously stopped in puddles of waste-water.

According to the researcher's assumptions, the good security of liquid waste for mothers who have toddlers cannot be separated from various factors, including economic factors, the majority of the community already has a liquid waste disposal channel that is connected directly to the public drainage which will be connected to the main drainage so that household fluids do not pollute the soil. around the house that can cause contamination of ground water or become a breeding ground for germs. As well as good knowledge and awareness of mothers about the risk of disease due to household waste fluids that are disposed of carelessly.

The proportion of stunting in children under five in the working area of the Sidomulyo Health Center, Pekanbaru, in 2021 is 60 people (36.8\%). There is a relationship between open defecation with the incidence of stunting in children under five $(\mathrm{OR}=$ 20.25; $\mathrm{p}<0.001)$. There is a relationship between washing hands with soap with the incidence of stunting in children under five $(\mathrm{OR}=14$. 09; $\mathrm{p}<0.001)$. There is a relationship between household drinking water and food management with the incidence of stunting in children under five $(\mathrm{p}<0.001)$. There is a relationship between household waste management and the incidence of stunting in children under five $(\mathrm{OR}=13.84$; $\mathrm{p}<0.001)$. There is a relationship between household liquid waste protection and the incidence of stunting in children under five $(\mathrm{OR}=11.90 ; \mathrm{p}<0.001)$.

Factors related to community-based total sanitation with the incidence of stunting in toddlers in the work area of the Sidomulyo Health Center, Pekanbaru, in 2021, namely open defecation, hand washing with soap, drinking water management and household food, household waste management and household liquid waste management.

The most dominant factors for stunting are stop opening open defecation, safe household waste and safe household liquid waste. It is hoped that health workers will be able to provide assistance to residents in getting assistance from the local government in an effort to improve the quality of latrine sanitation, household liquid waste by normalizing drainage and sewage ditches in the neighborhood of residents homes as well as providing hand washing facilities in public facilities and improving residents drinking water sources. both in the form of physical assistance and in terms of increasing knowledge of residents by providing education related to the management of drinking water for household food so that the health status of residents can increase so that the risk of stunting in children under five does not occur.

\section{AUTHOR CONTRIBUTION}

Auliya Fajriyati is the main researcher who selects the topic, searches for and collects research data. Novita Rany, Jasrida Yunita, Oktavia Dewi, Emy Leonita act as mentors

FUNDING AND SPONSORSHIP

This study is self-funded.

CONFLICT OF INTEREST

There is no conflict of interest in this study.

\section{ACKNOWLEDGMENT}

The researcher would like to thank the supervisor, Sidomulyo Health Center and parents who have contributed to the making of this thesis.

\section{REFERENCES}

Ahmadi, Sulistyorini L, Azizah R, Oktariza 
Fajriyati et al./ Community-Based Total Sanitation with Stunting Incidences in Toddlers

H (2020). Association Between Toilet Availability and Handwashing Habits and the Incidence of Stunting in Young Children in Tanjung Pinang City, Indonesia. Malaysian J. Med. Health Sci. E-ISSN 2636-9346. Available at: https://medic.upm.edu.my/upload/d okumen/2020042010323930_MJHS _0449.pdf

Budiman, Juhaeriah J, Abdillah AD, Yuliana B (2011). Hubungan sanitasi total berbasis masyarakat dengan kejadian diare pada balita di kelurahan Cibabat Kecamatan Cimahi Utara (The relationship of community-based total sanitation with the incidence of diarrhea in toddlers in Cibabat, North Cimahi District). Prosiding SNaPP: Sains dan Teknologi, Vol 2. Available at: http://proceeding.unisba.ac.id/index.php/sains_teknologi/article/view 1639.

Crocker J (2017). Sustainability of community-led total sanitation outcomes: Evidence from Ethiopia and Ghana. International Journal of Hygiene and Environmental Health. 3: 551-557. https://doi.org/10.1016/j.ijheh.2017.02.011.

Dainur (2015). Materi-Materi Pokok Ilmu Kesehatan Masyarakat (Main Materials of Public Health Ilmu). Jakarta. Widya Medika. Widya Medika: Jakarta.

Herawati H, Anwar A, Setyowati DL (2020). Hubungan sarana sanitasi, perilaku penghuni, dan kebiasaan cuci tangan pakai sabun (CTPS) oleh ibu dengan kejadian pendek (stunting) pada batita usia 6-24 bulan di wilayah kerja Puskesmas Harapan Baru, Samarinda (Relationship of sanitation facilities, occupants behavior, and handwashing habits with soap (CTPS) by mother with stunting in toddlers age 6-24 months in the working area of Harapan Baru Health Center, Samarinda). Jurnal Kesehatan Lingkungan Indonesia, 19(1): 7. Available at: http://creativecommons.org/licenses/by-nc-sa/4.o.

Kementerian Kesehatan RI (2011) Data dan Informasi Kesehatan Situasi Diare di Indonesia (Data and Health Information on Diarrhea Situation in Indonesia). http://www.depkes.go.id/download/Buletin. Retrieved September 20, 2021

Margareth (2012). Hubungan kondisi sanitasi total terhadap kejadian diare pada masyarakat di Kabupaten Sumedang dengan cakupan wilayah pengembangan Metropolitan Bandung tahun 2012 (The relationship of total sanitation conditions to the incidence of diarrhea in the community in Sumedang Regency with the Coverage of the Bandung Metropolitan development area in 2012). Tesis Universitas Indonesia.

Mukti DA, Raharjo M, Dewanti NAY (2016). Hubungan antara Penerapan program Sanitasi Total Berbasis Masyarakat (STBM) dengan Kejadian Diare di Wilayah Kerja Puskesmas Jatibogor Kabupaten Tegal (The relationship between the implementation of the Community-Based Total Sanitation (STBM) program with the incidence of diarrhea in the Jatibogor Health Center Work Area, Tegal Regency). J Kesehat. Masy. 4(3), 767-775. Retrieved from: https:// ejournal3.undip.ac.id/index.php/jkm/article/view/13535.

Permenkes (2014). Sanitasi Total Berbasis Masyarakat (Community Based Total Sanitation), Jakarta. Kemenkes RI. 